\title{
THE PLURALITY OF RELIGIOUS EDUCATION IN ISLAM PESANTREN DDI UJUNG LARE KOTA PAREPARE
}

\author{
${ }^{1}$ Dr. Herda, M.Pd., ${ }^{2}$ Drs. Abdul Rauf Ibrahim, M.Si \\ Dosen pada Fakultas Tarbiyah IAIN Parepare ${ }^{1,2}$ \\ herdamaesara@gmail.com
}

\begin{abstract}
: learning resources developed at pondok pesantren during this time oriented plurality. Good learning material PAl as well as religious tradition that held through extracurricular activities and kokurikuler are always paying attention to the teaching of the equation, the equation, the fraternity and compassion in Islam. Typology of religious learning resources that are rooted in Pesantren Putri DDI Lil Banat is an understanding of the religion institution of moderate, tolerant and inklusivisme. Pesantren as a religious educational institutions often compromised the spread understand religious radicalism. From this aspect, if the existence of boarding school instrumental more urgency in developing the views, attitudes towards the plurality of values.
\end{abstract}

Keywords: plurality, Islamic education, pesantren

\begin{abstract}
Abstrak: Sumber pembelajaran yang dikembangkan di pesantren selama ini berorientasi pada pluralitas. Baik materi pembelajaran PAI maupun tradisi keagamaan yang diselenggarakan melalui kegiatan ekstrakurikuler dan kokurikuler senantiasa memperhatikan ajaran persamaan, persamaan, persaudaraan dan kasih sayang dalam agama Islam. Tipologi sumber pembelajaran agama yang berakar di Pesantren Puteri DDI Lil Banat adalah pemahaman agama yang bercorak moderat, toleran dan inklusivisme. Pesantren sebagai institusi pendidikan keagamaan seringkali disusupi penyebaran faham radikalisme keagamaan. Dari aspek ini, jika keberadaan pesantren berperan lebih urgensi dalam mengembangkan pandangan, sikap terhadap nilai-nilai pluralitas.
\end{abstract}

Kata kunci: Pluralitas, Pendidikan Agama Islam, Pesantren 


\section{PENDAHULUAN}

Pluralitas (kemajemukan) yang menandai kehidupan sosial masyarakat tidak hanya terjadi pada keragamaan etnis yang jumlah angkanya demikian banyak, juga terjadi pada agama dan kepercayaan yang dianut oleh setiap warga yang jumlah beragam, seperti Islam, Katolik, Protestan, Hindu, Budha, dan Kong Ho Chu, dan sejumlah kepercayaan dan aliran lokal yang berkembang di tengah-tengah masyarakat.

Kemajemukan dapat dilihat dari perspektif kebaikan dan keburukan. Dari aspek perspektif kebaikan yaitu menjadi modal dasar dan modal sosial dalam sistem sosial dan budaya. Karena ia merupakan potensi yang dibutuhkan dalam pembangunan kehidupan sosial. Jika hal itu dikelola dengan cara-cara dan pendekatan yang tepat, serta disikapi dengan arif. Sebaliknya, akan menjadi potensi laten yang dapat mendorong terjadinya letupan pertentangan, kerusuhan, bahkan konflik yang menjurus terjadinya anarkisme. Selanjutnya dapat berkembang menjadi sesuatu yang sistemik berpotensi menimbulkan perpecahan dan menyebabkan kemunduran dalam masyarakat.

Kenyataan sosial masyarakat Indonesia adalah bercorak pluralitas. Kemajemukan sosial dianggap sebagai persoalan tampak terutama saat meletus menjadi konflik kepentingan atas dasar agama dan etnik. Di Indonesia, gejala konflik dan rusuh seringkali terjadi dalam peta sosial, kerusuhan massal yang terjadi seperti di Sambas, Ambon, Papua dan Aceh. Di samping konflik yang berskala makro yang menimbulkan ekses negatif terhadap psikhis dan integrasi sosial, juga seringkali tampak kepermukaan adanya konflik yang berskala kecil yang sangat mengganggu toleransi di antara anggota masyarakat, baik toleransi internal umat beragama maupun toleransi antara umat beragama.

Pada aspek lain, realitas sosial pada masyarakat menjadi sesuatu kemustahilan jika dipaksakan kepadanya tentang faham homogenitas budaya dan agama. Jika dilakukan merupakan upaya menentang tabiat sosial yang secara alamiah diperkaya oleh sejumlah keragaman budaya dan agama. Setiap anggota masyarakat mengalami pertumbuhan dan berinteraksi dengan keadaan latar belakang yang berbeda. Sikap homogenitas budaya dan agama justeru akan menjadi bara api yang menyala dalam sekam, sewaktu-waktu akan meledak dengan api ledakan yang dahsyat. Untuk itu, pandangan homogenitas tidak dibutuhkan untuk menciptakan keserasian dalam masyarkat, karena disamping menyalahi prinsipprinsip persamaan dan sederejat serta demokratis, juga sama halnya memelihara fungsi laten potensi destruktif dalam masyarakat. Dari aspek ini, yang dibutuhkan sesungguhnya adalah meraju perbedaan ke dalam visi persamaan dan keadilan serta kebersamaan sebagai sesame anggota masyarakat.

Fenomena sosial merupakan pewujudan atas keragaman latar belakang di antara anggota-anggotanya, tujuan keragaman itu dari perspektif agama Islam adalah untuk menguatkan silaturrahim dan saling mengenal. Doktrin agama mengakui, dan 
mengajarkan agar setiap umat senantiasa bersikap, berpandangan, dan berperilaku menerima perbedaan. Perbedaan dapat direkatkan dengan kesadaran untuk saling bekerja sama membangun kekuatan keutuhan.

Masing-masing agama mempunyai ajaran (dotrin) yang menghargai dan menghormati perbedaan, yaitu menghormati terhadap keberadaan agama lain. Dalam Islam, sudah jelas aturan normatifnya, yaitu sesuai penegasan kitab Suci Al-Qur'an, terjemahnya "Bagimu agamamu dan bagiku agamaku." Ayat ini menegaskan bahwa toleransi, kebebasan beragama bukan merupakan suatu paksaan yang dilakukan baik secara kultural maupun secara structural, melainkan dilakukan atas kesadaran untuk memilih agama yang diinginkan.

Suatu kenyataan bahwa struktur masyarakat terdiri atas beragam latarbelakang dengan tingkat kemajukan yang tinggi. Kemajemukan yang berdasar pada perbedaan suku, ras, bahasa, budaya dan agama, serta pola-pola relasi sosial. Kemajemukan dapat dikatakan sebagai sesuatu yang dapat berfungsi kontraprofuktif. Pada dasarnya, keragaman mempunyai aspek positif dan sehat serta sekaligus dapat alat yang potensial dalam mendorong keutuhan dengan pola jaringan kerjasama, sekaligus mengenyampingkan unsur-unsur perbedaan yang dapat menimbulkan konflik.

Juga tidak dapat dipungkiri, bahwa kemejemukan seringkali menjadi pemicu terjadinya ketegangan, gesekan, persaingan bahkan konflik yang berujung pada anarkisme. Di mana masyarakat seringkali menjadikan agama sebagai media untuk saling bermusuhan, menyebar kebencian, ketegangan di antara anggota masyarakat. Pada hal agama sangat menjunjung tinggi perilaku dan sikap hidup berdampingan dengan umat lain, meskipun berbeda latar belakang. Kemajemukan yang ditandai dengan keanekaragaman agama itu mempunyai kecenderungan kuat terhadap identitas agama masing-masing dan berpotensi konflik.

Dengan demikian, agama seharusnya oleh penganutnya, difungsikan sebagai simbol pergaulan dan penegasan identitas semata-mata, bukan dimaksudkan untuk memperlihatkan sikap superioritas di tengah-tengah penganut agama lain. Jika demikian keadaannya, maka agama kehilangan fungsi sosialnya sebagai wadah keutuhan sosial. Setiap umat beragama mempunyai ruang yang sama untuk mengekspresikan simbol dan identitas keyakinannya, dan yang lainnya tidak mempunyai hak dan kewenangan dalam memaksakan keseragaman.

Untuk itu dalam kehidupan sosial, agama harus dilihat dari aspek-aspek koneksitas, persamaan dan kesetaraannya atas dasar tetap menjaga prinsip keyakinan, bukan mengedepankan segi perbedan yang berpotensi menimbulkan konflik. Meskipun dalam Islam mengajarkan cara hidup sosial, yaitu menjadi umat yang satu (ummah wahidah); konsep kesatuan dalam ikatan agama Islam yang normatifnya tertuju kepada internal umat, namun konsep itu tidak serta merta mendorong umat Islam dan missi agamanya agar bersikap eksklusivisme terhadap agama dan budaya yang ada.

Berdasarkan kondisi interpretasi agama oleh masyarakat yang cenderung subyektif, dan diaplikasikan sebagai alat pemicu terjadinya konflik, maka konsep 
Pendidikan Agama Islam yang berorientasi koneksitas, persamaan dan kesetaraan antara sesama warga merupakan hal yang perlu dikembangkan.

Pendidikan Agama Islam sejiwa dan sejalan dengan spirit sosial yang menjadi konsep hidup sebagai ajaran Islam. Untuk itu ke arah itulah, Pendidikan Agama Islam diformulasi dan diperkenalkan untuk mengembangkan potensi individual yang memahami dan menerima kemajemukan.

Disadari bahwa Pendidikan Agama Islam yang sedang berjalan kurang mengaktualisasikan potensi kekhalifaan individu dan memberikan penekanan pada pengembangan potensi kehambaan individu, seharusnya memperhatikan keseimbangan antara keduanya. Pendidikan Agama Islam harus difungsikan sebagai transmisi etika sosial yang berintikan kedamaian dan keharmonisan di tengah masyarakat.

Pengembangan wawasan pluralitas melalui wadah pendidikan agama Islam di kalangan siswa adalah hal yang sangat penting, dan tepat mengingat munculnya gejala cara pandang agama yang cenderung homogen, hal ini terjadi yang memanfaatkan lembaga pendidikan agama sebagai wadah penyebaran faham yang cenderung eklusif seperti itu.

Berdasar pada persoalan-persoalan tersebut di atas, maka di antara berbagai upaya yang ditempuh adalah melalui institusi pendidikan, secara khusus melalui lembaga pendidikan pesantren. Pendidikan, sebagai salah satu institusi penting dalam pembangunan kehidupan sosial memiliki peran yang penting dan strategis dalam pemecahan potensi konflik pluralisme. Dengan peran yang demikian penting itu, maka institusi pendidikan mempunyai peluang untuk mentransfer pandangan pluralisme, menghormati dan menerima perbedaan budaya dan agama dalam bingkai persamaan dan sederajat, kepada peserta didik.

Melalui institusi pendidikan pesantren, seorang ustadz (sebagai pendidik) dapat memainkan peran penting. Dengan kapasitasnya sebagai pendidik yang disegani dan dihormati oleh peserta didiknya, maka ia dapat menyampaikan ajaran agama yang diyakini, menanamkan ketaatan pada aturan normatif agama, menumbuhkan kesadaran kepada peserta didik agar termotivasi melindungi dan menyebarkan agamanya. Selain itu, yang terpenting adalah membentuk pandangan, pemahaman, sikap hidup peserta didik untuk dapat berinteraksi antar beragam pemeluk agama secara harmonis, persaudaraan, tanpa perlu mempersoalkan perbedaan kepercayaan.

Perilaku dan sikap hidup yang berbasis pada toleransi yang tinggi terhadap penganut agama dan kepercayaan yang lain melalui lembaga pendidikan pesantren dapat diwujudkan. Pesantren memiliki kemampuan dalam mewujudkannya, karena (1) pesentren mempunyai sumber daya manusia, dengan kapasitas pendidik yang memahami ajaran toleransi hidup yang menjadi ajaran Islam, (2) keberadaan pesantren pada dasarnya sebagai institusi pendidikan keagamaan yang bertanggung jawab mengenai pemahaman agama yang benar terhadap peserta didik, (3) keberadaan lain, yaitu memiliki tanggung jawab untuk melindungi pemahaman dan pandangan keagamaan yang berkembang di tengah-tengah masyarakat, terutama 
pandangan yang mengarah eksklusivisme keagamaan, (4) pola interaksi sosial di pesantren dilator belakangi oleh perbedaan suku, ras, budaya, dan bahasa, seyogiyanya hal-hal itu menjadi sumber inspirasi dalam membangun sikap toleransi dengan pemeluk agama yang berbeda.

Karenanya adalah sangat menarik untuk mengkaji pengembangan Pendidikan Agama Islam (PAI) dari perspektif kemajemukan, di tengah merebahnya pandangan radikalisme merambah masuk ke dunia pesantren. Pesantren sebagai institusi pendidikan keagamaan seringkali disusupi penyebaran faham radikalisme keagamaan. Dari aspek ini, jika keberadaan pesantren berperan lebih urgensi dalam mengembangkan pandangan, sikap terhadap nilai-nilai pluralitas.

\section{METODE PENELITIAN}

\subsection{Jenis dan Desain Penelitian}

Sejalan dengan karakteristik obyek, metode dan pendekatan yang digunakan dalam penelitian ini adalah jenis penelitian kuantitatif, yaitu penelitian yang memaparkan data emperis dengan menggunakan angka atau bilangan (numeric), dan alur metodologinya menggunakan teknik deduktif. Fokus penelitian ini adalah mencari korelasi dari dua jenis variabel, yaitu variabel stimulus dan variabel yang dipengaruhi. Adapun variabel yang menjadi sumber instrumen analisis data, adalah materi Pendidikan Agama Islam sebagai variabel (X1), dan kegiatan Pendidikan Agama Islam sebagai variabel (X2), Desain penelitian ini adalah gambarannya sebagai berikut;

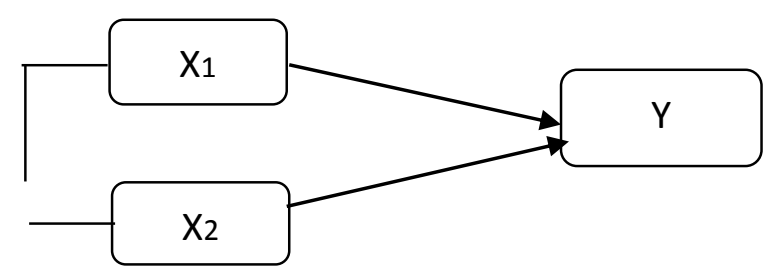

Keterangan:

$\mathrm{X} 1=$ Materi Pendidikan Agama Islam (PAI)

$\mathrm{X} 2=$ Aktivitas Pendidikan Agama Islam (PAI)

$\mathrm{Y} \quad=$ Penerimaan santri terhadap keragaman sosial

\subsection{Lokasi dan Waktu Penelitian}

Penelitian dengan fokus obyeknya yaitu Pondok Pesantren Puteri DDI Lil Banat Ujung Lare Parepare. Waktu penelitian dilaksanakan selama tiga bulan, meliputi kegiatan (1) persiapan dan pembuatan proposal, (2) penyusunan instrumen pengumpulan data, (3) uji instrumen pengumpulan data, (4) peliputan data di lapangan, (5) pengolahan data, (6) penyusunan laporan penelitian, (7) seminar laporan hasil penelitian, (8) finalisasi laporan hasil penelitian. Dilihat dari segi waktu 
yang digunakan dalam hubungannya dengan proses kegiatan penelitian, maka penelitian ini berlangsung selama empat bulan, adalah sebagai berikut: (1) tahapan persiapan selama satu bulan, (2) tahapan kegiatan penelitian selama dua bulan, dan (3) tahapan penyelesaian selama 1 bulan.

\subsection{Populasi dan Sampel}

Dalam kaitannya dengan penelitian ini, maka populasinya adalah para santri sebagai peserta didik, secara formal diakui keberadaannya. Populasi yang menjadi obyek penelitian berjumlah 247 orang, untuk tingkat Madrasah Tsanawiyah (M.Ts S) sebanyak 67 orang, dan tingkat Madrasah Aliyah (MAS) sebanyak 180 orang. Populasi tersebut, sebagiannya ditetapkan sebagai sampel penelitian. Penentuan sampel sudah barang tentu mempertimbangkan unsur-unsur refresentatifnya atau keterwakilan suatu sumber data secara obyektif.Teknik sampling yang digunakan adalah teknik sampling random (secara acak).

\subsection{Metode dan Instrumen Pengumpulan Data}

Dalam hal ini, peneliti menggunakan beberapa metode dan instrumen pengumpulan data, sebagai berikut:

3.4.1 Metode observasi, adalah cara pengumpulan data di mana peneliti mengamati obyek permasalahan.

3.4.2. Metode wawancara, adalah peneliti melakukan interview dengan sejumlah informan. Penggunaan metode interview dimaksudkan untuk memperoleh data secara lisan dari sumber yang dinilai tepat dan memahami persoalan.

3.4.3 Metode dokumen, yaitu menjadikan arsip, catatan resmi sebagai sumber data.

3.4.4 Metode Angket, yaitu daftar pertanyaan tertulis yang memerlukan jawaban tertulis pula dari responden (santri peserta didik) yang ditentukan secara acak atau random setiap instrumen pertanyaan.

\subsection{Teknik Analisis Data}

Penelitian ini adalah jenis kuantitatif, untuk teknik analisisnya menggunakan analisis pendekatan statistik. Oleh karenanya, maka data kuantitatif dijadikan sebagai bahan analisis, sementara data kualitatif yang diperlukan dirubah menjadi data kuantitatif. Adapun teknik untuk merubah data yang sifatnya kualitatif menjadi data kuantitatif dengan cara membuatkan rating scale, dikategorisasi sesuai dengan bobot data yang dijaring dari responden. Selanjutnya, teknik untuk menganalisis data yang digunakan dalam penelitian ini, adalah pengujian terhadap data sampel yang sifatnya deskriptif dengan cara melaksanakan uji-normalitas data dan sekaligus menentukan nilai frekuensi kumulatif data. Data sampel deskriptif terdiri atas, yaitu data X1 dan $\mathrm{X} 2$ (variabel independen), serta data $\mathrm{Y}$ (variabel dependen). Pengujian hipotesis deskriptif dengan t-test satu sampel, meliputi kualitatif dari masing-masing hipotesis terhadap permasalahan. 


\section{HASIL}

Penelitian ini difokuskan pada obyek mengenai penerimaan oleh para santri DDI Lil Banat terhadap kemajemukan (pluralitas) sebagai implikasi dari materi pembelajaran Pendidikan Agama Islam (PAI) dan aktivitas pembelajarannya yang berisi muatan sikap dan pandangan pluralis. Skor tertinggi untuk setiap instrumen adalah nilai 4 (nilai kuantitas) yang dikonversi atas data kualitas dari responden terhadap setiap pertanyaan instrumen angket.

Dengan demikian cara melakukan pengskoran adalah menggunakan rumus $4 \times 15 \times 110=6.600$, sementara untuk mengetahui skor persentasenya adalah menjumlahkan nilai instrumen variabel penelitian, apakah variabel $X 1$ ataukah variabel X2, sama halnya dengan variabel Y.Berdasarkan hal tersebut, maka diperoleh gambaran bahwa bahwa tingkat kategorisasi jawaban responden terhadap variabel X1 dan X2 adalah berada pada level yang kuat. Kegiatan pengumpulan data melalui proses penelitian berupa jawaban responden terhadap angket, sebelum dianalisis, dipaparkan secara deskriptif berdasarkan teknik statistik, yaitu:

\section{Pengujian Normalitas Data}

Penelitian tentang kemajemukan (pluralitas) berfokus pada pandangan, sikap penerimaan santri terhadap perbedaan dengan latarbelakang agama, ras, suku, bahasa sebagai gejala sosial yang tidak dapat dihindari. Penelitian ini menggunakan tiga variabel berupa, yaitu: (1) materi pembelajaran Pendidikan Agama Islam (PAI), (2) aktivitas pembelajaran Pendidikan Agama Islam (PAI), dan (3) penerimaan santri terhadap kemajemukan (pluralitas). Data yang terkait dengan variabel deskriptif, setelah ditabulasikan, selanjutnya dipaparkan dengan teknik frekuensi nilai variabel, dan uji normalitas data. Sementara data yang terkait dengan variabel yang berkaitan dengan hubungan signifikan atau korelasi, dianalisis dengan menggunakan teknik analisis product moment secara sederhana. Hal ini dimaksudkan untuk mencari pengaruh antara variabel independen $(X)$ dengan variabel dependennya $(Y)$.

Pengujian data menggunakan teknik t-tes, selanjutnya dianalisis sesuai dengan teknik statistik, kegiatan itu diawali dengan pemberian skor pada jawaban responden yang didasarkan pada kategorisasi untuk menentukan tingkat kualitas jawaban atas angket. Skor tertinggi untuk satu instrumen adalah 4 (empat), dan skor terendah 1 (satu), sedangkan jumlah instrumen (alat ukur) dari setiap variabel adalah 15 butir. Hal ini berarti bahwa skor kriterium adalah $4 \times 15=60$ untuk 110 responden dari masing-masing variabel atau sama halnya $60 \times 110=6.600$ skor. Skor ini merupakan standar maksimal yang menunjukkan tingkat kecenderungan data. Sehingga dengan standar ini, maka kecenderungan data dari masing-masing variabel dapat diketahui nilai persentasenya. 
Pemaparan data secara deskriptif untuk masing-masing variabel seperti terlihat di bawah ini:

\section{Materi Pembelajaran PAl}

Materi pembelajaran PAI merupakan salah satu komponen yang dapat berperan dalam mempengaruhi sikap, pandangan dan penerimaan santri terhadap realita sosial masyarakat. Aspek pengetahuan atau pemahaman keagamaan akan dimanifestasikan dalam bentuk sikap, perilaku sesuai dengan tipe-tipe pemahaman keagamaan. Untuk itu jika pengetahuan tentang keagamaan dipahamni dengan pemahaman secara eklusif, maka refleksi pengamalannya akan cenderung fanatic dan ekstrim. Disinilah pentingnya, aspek pengetahuan keagamaan yang senafas dengan substansi ajaran al- Qur'an dan al- Hadits yang tepat tentang kemajemukan diajarkan kepada penserta didik.

Berdasarkan hasil tabel frekuensi dari Angket 2015 tampak bahwa materi Pembelajaran PAI jika diberi skor, maka skor kriterium yang terendah 15 dan kriterium tertingginya adalah 60. Karena distribusi kecenderungannya berdasarkan dari 110 responden, terlihat bahwa yang paling rendah (15-19) sebanyak 4 responden (3,63 $\%$ ), sedangkan skala yang tertinggi (55-60) sebanyak 13 responden ( $11,82 \%)$. Adapun skor jawaban yang tertinggi berada pada interval 35- 39 yaitu sebanyak 24 responden $(21,82 \%)$, selain itu, terlihat pula skor jawaban yang paling rendah pada interval 15 - 19 yaitu 4 responden (3,63\%), selanjutnya pada interval 25 - 29 yaitu 5 responden ( $4,55 \%)$. Berdasarkan tabel jika dipersentasekan maka akan terlihat perhitungannya, adalah 110 (jumlah responden) x 60 (kriteria skor yang tertinggi); $110 \times 60=6.600$, sehingga hasilnya; $4.337: 6.600 \times 100 \%=65,71 \%$. Persentase ini menunjukkan bahwa materi pembelajaran PAI yang diajarkan mempunyai muatan pluralitas, kebanyakan responden memberikan jawaban mencapai 65, 71\% dari 110 orang. Hal di atas menunjukkan bahwa jawaban responden berada pada kisaran atau kategori sedang.

Distribusi skor tentang aktivitas pembelajaran PAI yang berisi muatan tentang kemajemukan yang terendah pada level (25-29) sebanyak 5 responden (4,55\%), dan tertinggi pada interval (50-54) sebanyak 21 responden (19,09\%). Sedangkan tingkat presentasenya maka perhitungannya adalah $110 \times 60=6.600$, sementara nilai variabelnya adalah 5.756. Dengan demikian, hasilnya; $4.517: 6.600 \times 100 \%=68$, $43 \%$. Hal ini memberi gambaran bahwa responden menilai aktivitas pembelajaran yang bermuatan kemajemukan mencapai $68,43 \%$. Persentase ini tidak berbeda jauh dengan materi pembelajaran yang bermuatan kemajemukan mencapai 65,71 \%. Hal ini dapat dijadikan dasar penilaian bahwa pandangan tentang kemajemukan merupakan bagian tidak terpisahkan dalam proses pembelajaran PAI. Pada setiap kegiatan pembelajaran, guru PAI berperan aktif dalam memberikan pemahaman kepada santri tentang nilai-nilai toleransi dalam kehidupan sosial. Berdasarkan tabel hasil kumulatif dari angket 2015 tampak bahwa data tentang aktivitas pembelajaran PAI menunjukkan sebaran yang merata atau berdistribusi normal. Dengan demikian dapat dianalisis dengan mencari hubungan signifikan atau korelasinya dengan variabel lain. Skor terbanyak pada level kriterium yang tertinggi 54,5 sekitar 21 
responden atau 19,09\%, sedangkan yang terendah pada kriterium 29,5 sekitar 5 responden atau 4,55 \% dari 110 responden. Terjadi kecenderungan positif yaitu skala grafik pada persentase frekuensinya mengalami kenaikan hingga pada level $100 \%$, data ini membuktikan dapat diuji hipotesisnya.

\subsubsection{Penerimaan Responden terhadap Pluralitas.}

Pluralitas (kemajemukan) diartikan sebagai suatu entitas yang menunjukkan perbedaan yang beragam corak latarbelakangnya, dari suku, bangsa, ras, bahasa, maupun agama. Keberagaman dalam masyarakat yang pluralistik merupakan bagian yang menyatu dengan sistem sosial kemasyarakatan, dan harus diterima sebagai suatu modal sosial. Berdasarkan hasil frekuensi dari angket 2015 menggambarkan bahwa tingkat penerimaan santri terhadap kemajemukan (pluralitas) mencapai skor nilai tertinggi pada level (55-60) sekitar 25 responden atau 22,73\%, sedangkan skor nilai yang terendah pada level ( 20-24 ) sekitar 5 resonden atau hanya 4,55 \% dari 110 responden. Data di atas juga menunjukkan persentase penerimaan terhadap kemajemukan soal, yaitu $110 \times 60=6.600$, sedangkan nilai variabelnya ( $\mathrm{Y}$ ) adalah 6.096, sehingga hasilnya; $4.759: 6.600 \times 100 \%$ adalah 72, 10\%. Data ini secara deskriptif menggambarkan bahwa dari sebanyak 110 responden, maka tingkat penerimaan terhadap kemajemukan mencapai $72,10 \%$.

Data tersebut di atas, sebagai data deskriptif, menunjukkan kecenderungan positif yang menggambarkan sikap, pandangan responden untuk mengakui dan menerima kemajemukan sebagai realitas sosial kemasyarakatan. Kecenderungan penerimaan oleh santri, dimungkinkan dipengaruhi oleh tradisi hidup dipesantren yang senantiasa mengaplikasikan kebersamaan di antara sesama mereka. Dengan demikian dapat dipahami bahwa pandangan dan penerimaan santri terhadap kemajemukan merupakan bagian dari sistem pendidikan Islam yang mempengaruhinya. Distribusi nilai kumulatif penerimaan responden terhadap kemajemukan rata-rata menunjukkan sikap positif yang mencapai nilai kurang dari 59,5 sebanyak 25 responden atau $22,73 \%$, sedangkan skor kumulatif yang terendah adalah 24,5 sebanyak 5 responden atau 4,55\%, sedangkan termasuk kategori sedang pada frekuensi 39,5 sebanyak 24 responden atau 21,82\%. Seperti halnya dengan variabel sebelumnya, maka variabel $Y$ menunjukkan bahwa data mengalami grafik peneingkatan pada persentase frekuensi sampai ke level 100\%.

\section{Pengujian Hipotesis Deskriptif}

Dalam hal ini, yang dimaksud adalah melakukan pengujian hipotesis secara deskriptif terhadap satu variabel, sebagai titik tolak untuk melakukan uji korelasi, mengujinya dengan t-test satu sampel. Uji hipotesis dimulai dengan menentukan nilai rata-rata kriterianya, dengan perkiraan bahwa hipotesis mencapai kategori sedang, yaitu $60 \%$ atau 0,6, sedangkan rata-rata kriteriumnya adalah 60 , yang berarti 0,6 x $60=36$ (rata-rata kriteriumnya). 
Uji hipotesis variabel X1 ( Materi Pembelajaran PAI), dalam hipotesis dinyatakan bahwa "materi pembelajaran PAI berisi muatan Pluralitas (kemajemukan) dikategorikan sedang", dalam menguji hipotesis deskriptif ini terlebih dahulu menghitung simpanan bakunya $(\delta)$, adapun rumus yang digunakan adalah sebagai berikut:

$$
\begin{aligned}
& S=\frac{\sqrt{\sqrt{(4.337-39,44)}^{2}}}{110-1} S=\frac{\sqrt{\sqrt{8.595,12}}}{110-1}=78,87 S=\sqrt{78,87}=8,789 \\
& \mathrm{t}=(39,44-36) \frac{=8,789}{\sqrt{\sqrt{110}}} \\
& \mathrm{t}=3,44=0,838 \quad \mathrm{t}=4,105
\end{aligned}
$$

Untuk menentukan apakah hipotesis diterima, maka t hitung 4, 105, sesuai dk (derajat kebebasannya) sebesar $110-1=109$, dan menggunakan taraf kesalahan 5 $\%$, maka diperoleh hasil bahwa ternyata t- hitung sebesar 4, 105 terletak di luar harga t-tabel, yaitu 1, 656. Hal ini dapat disimpulkan bahwa hipotesis yang menyatakan bahwa materi pembelajaran PAl berisi muatan pluralitas (kemajemukan) dikategorikan berada pada level di atas sedang, diterima. Beradasarkan perhitungan sampel, ternyata bahwa materi pembelajaran PAI berisi muatan kemajemukan berada di atas $60 \%$. Jadi terjadi kesesuaian antara data yang diperoleh di lapangan dengan data yang diduga.

Variabel hipotesis $\mathrm{X} 2$, dalam hipotesis dinyatakan bahwa "aktivitas pembelajaran PAI berisi muatan tentang pandangan kemajemukan berada dalam kategori sedang," dalam mengujinya terlebih dahulu dikemukakan simpanan bakunya (s), selanjutnya diuji dengan uji t-test. Dengan rumus perhitungan, sebagai berikut:

$$
\begin{aligned}
S & =\frac{\sqrt{(4.517-41,064)}^{2}}{110-1} \quad S=\frac{\sqrt{\sqrt{8.951 .872}}}{109}=82,127 \\
S & =\sqrt{\sqrt{82,127}=9,062} \\
\mathrm{t} & =(41,064-36)=\frac{9,062}{\sqrt{ } 110} \\
\mathrm{t} & =5.064=0,86 \mathrm{t}=5,862
\end{aligned}
$$

Berdasarkan perhitungan pengolahan data yang terkumpul, yaitu t- hitung sebesar 5, 862, ternyata terdapat perbedaan dengan apa yang diduga (hipotesis), hal menunjukkan bahwa hipotesis alternatif diterima. Berdasarkan t hitung 5, 862, disesuaikan dk (derajat kebebasannya) sebesar $110-1=109$, dan menggunakan taraf kesalahan 0,5\%, sehingga t- hitung sebesar 5, 862 terletak di luar harga t-tabel 1, 656. Jadi dapat disimpulkan bahwa hipotesis yang menyatakan aktivitas pembelajaran PAI mengandung muatan kemajemukan berada pada kategori sedang, ditolak. Karena datanya, sesuai hasil perhitungan uji data deskriptif, membuktikan di atas kategori sedang ( $\mathrm{t}$ hitung $=5,862>\mathrm{t}$-tabel $=1,656$ ).

4.2.1.3 Hipotesis deskriptif dari variabel dependen $(Y)$, dinyatakan dengan hipotesis bahwa" penerimaan santri terhadap pluralitas (kemajemukan) berada pada 
kategori yang sedang", adapun pengujian hipotesisnya dimulai dengan menghitung simpanan bakunya (s), selanjutnya diuji dengan t-test, adalah sebagai berikut:

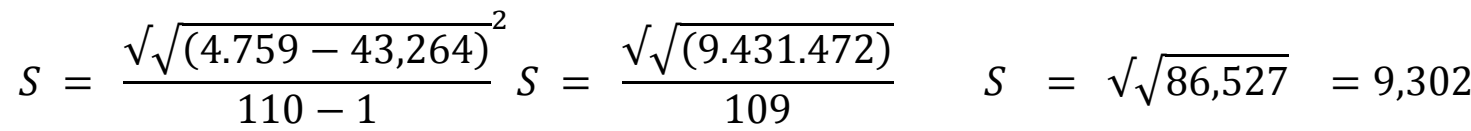

$$
\begin{aligned}
& T=(43,264-36)=\frac{9,302}{\sqrt{ } \sqrt{110}} \\
& \mathrm{t}=7,264=0,887 \mathrm{t}=8,189
\end{aligned}
$$

Data mengenai penerimaan responden terhadap pluralitas (kemajemukan), setelah dianalisis, ternyata hipotesis bahwa" penerimaan (berupa pandangan dan sikap) terhadap pluralitas berada pada kategori sedang, adalah sesuai dengan apa yang diduga (hipotesis). Berdasarkan dengan t hitung 8, 189, sesuai dk (derajat kebebasannya) sebesar $110-1=109$, dan menggunakan taraf kesalahan 0,5\%, maka diperoleh hasil bahwa ternyata t- hitung sebesar 8,189 jauh lebih tinggi harganya dengan t-tabel 1,656. Dengan demikian dapat disimpulkan bahwa hipotesis yang menyatakan penerimaan responden tentang pluralitas dapat dikateogrikan sedang, diterima.

\section{Pengujian dengan Hipotesis Asosiatif}

Setelah uji hipotesis deskriptif, selanjutnya pada bagian ini adalah pengujian hipotesis asosiatif, yaitu mencari hubungan dari dua variabel yang menyatakan bahwa; 1) terdapat pengaruh positif atau signifikan antara materi pembelajaran PAI dengan penerimaan santri terhadap pluralitas, dan 2) terdapat korelasi yang signifikan antara aktivitas pembelajaran PAI dengan penerimaan santri terhadap kemajemukan, dan 3) terdapat korelasi yang signifikan anatara materi pembelajaran PAI dengan aktivitas pembelajaran PAI di Pesantren Puteri DDI Lil Banat. Untuk menguji hipotesis ini digunakan rumus, sebagai berikut;

$$
\text { ryx1 ryx2 }=\frac{\sqrt{\sum x y}}{\sqrt{\left(\sum_{x}^{2}\right)\left(\sum_{y} 2\right)}}
$$

Keteramgan:

ryx1 = pengaruh antara $X 1$ dengan $Y$

ryx 2 = pengaruh antara $\mathrm{X} 2$ dengan $\mathrm{Y}$

$\sum x y=$ jumlah nilai $\mathrm{X}$ dan $\mathrm{Y}$

4.2.1 Hipotesis asosiatif variable $\mathrm{X} 1$ dengan $\mathrm{Y}$, dinyatakan bahwa terdapat pengaruh antara materi pembelajaran Pendidikan Agama Islam (PAI) dengan penerimaan santri terhadap pluralitas (kemajemukan), dihitung atas dasar data yang diperoleh melalui angket, adalah sebagai berikut: 


$$
\begin{aligned}
r_{y x_{1}}= & \begin{array}{l}
189.227 \\
\sqrt{ } \sqrt{(182.891)}(227.767)
\end{array} \\
& \sqrt{189.277} \quad \frac{189.277}{204.099,324 \quad r_{y x_{1}}=0,927}
\end{aligned}
$$

Berdasarkan hasil analisis data tersebut di atas, bahwa terdapat pengaruh yang positif sebesar 0,927 antara materi pembelajaran Pendidikan Agama Islam (PAI) dengan sikap dan pandangan penerimaan santri terhadap pluralitas. Berdasarkan koefesien korelasinya terletak pada interval koefesien 0,80 - 1,00, maka pengaruh ini termasuk hubungan yang kuat, sebesar 0,927. Hasil korelasi ini jika dibandingkan $r$ - tabel ternyata lebih tinggi. Perbandingannya adalah 0,927 ( $\mathrm{r}$ hitung) $>$ 0,175 ( $r$ - tabel). Dengan demikian, hipotesis diterima, yaitu terdapat hubungan signifikan antara variabel $X 1$ dengan $Y$ (terdapat pengaruh yang signifikan atau positif antara materi pembelajaran PAI dengan penerimaan santri terhadap pluralitas). Hasil ini masih berlaku untuk sampel penelitian.

Untuk mengetahui apakah pengaruh ini berlaku tidak terbatas pada sampel penelitian atau tidak dapat digenaralisasikan untuk populasi, akan tapi korelasi ini juga dapat diberlakukan terhadap populasi, yaitu sikap penerimaan santri terhadap kemajemukan (pluralitas), maka hal ini diuji dengan t-test, sebagai uji signifikansinya adalah berikut:

$$
\begin{gathered}
t=\frac{0,927 \sqrt{\sqrt{110-43}}}{\sqrt{\sqrt{1-0,927^{2}}}}= \\
7,881 \\
t=\frac{-----=7,347}{\sqrt{ } \sqrt{0,146}}
\end{gathered}
$$

Jika t-hitung sebesar 7,347 dikonsultasikan dengan t-tabel untuk kesalahan (nilai error) $0,5 \%$, maka diketemukan t-tabel 1,980. Dengan demikian, dapat dinyatakan bahwa hipotesis alternatif yang diterima, sementara hipotesis nol ditolak. Jadi kesimpulannya koefesien korelasi antara materi pembelajaran PAI dengan sikap, pandangan terhadap penerimaan pluralitas sebesar 7,347 adalah signifikan, dan dapat digeneralisasi terhadap populasi.

4.2.2 Hipotesis asosiatif variabel $\mathrm{X} 2$ dengan $\mathrm{Y}$, dinyatakan bahwa terdapat pengaruh positif atau hubungan signifikan antara aktivitas pembelajaran PAI dengan penerimaan santri terhadap pluralitas di pesantern Puteri DDI Lil Banat di Kota Parepare. Adapun analisis datanya adalah sebagai berikut;

$$
\begin{aligned}
& \begin{array}{ll}
r_{y x 2}= & 193.532
\end{array} \\
& \sqrt{\sqrt{((200.875))(227.767)}} \\
& 193.532 \\
& 193.532
\end{aligned}
$$




$$
\sqrt{\sqrt{\sqrt{213.898}}, 78 \quad 213.898,79} \quad r_{y x_{2}}=0,905
$$

Korelasi ini menunjukkan pengaruh positif antara aktivitas pembelajaran PAI dengan penerimaan santri terhadap pluralitas sebesar 0,905, jika diletakkan pada interval koefesien, ternyata sangat kuat. Adapun tingkat signifikan pengaruhnya adalah $r$ hitung $0,905>0,175$ dibandingkan dengan $r$ tabel. Korelasi in berlaku hanya untuk sampel penelitian, atas dasar itu akan dicari koefesien korelasi dengan populasinya. Adapun mengenai perhitungannya adalah sebagai berikut;

$$
\begin{aligned}
& t=\frac{0,905 \sqrt{\sqrt{110-43}}}{\sqrt{\sqrt{1-0,905^{2}}}}= \\
& 7,887 \\
& \mathrm{t}=\quad \begin{array}{l}
-{ }^{2} \\
\sqrt{0,190}
\end{array}=6,443
\end{aligned}
$$

Berdasarkan perhitungan di atas, t-hitung sebesar 6, 443 jika dikonsultasikan dengan t-tabel sebesar 1,980 pada tingkat standar error 0, 5\%, maka dapat disimpulkan bahwa koefesien korelasi penelitian menunjukkan bahwa hasil analisis data tersebut dapat dipahami, bahwa hipotesis itu dapat diberlakukan secara generalisasi terhadap populasi, tidak terbatas pada sampel responden. Perbandingannya adalah t-hitung 6,443 >t-tabel 1,980. Pengujian hipotesis asosiatif antara variabel $\mathrm{X} 1$ dengan $\mathrm{X} 2$ (materi dan aktivitas pembelaran $\mathrm{PAI}$ ) dengan variabel $Y$ (penerimaan santri terhadap pluralitas). Adapun hipotesisnya, yaitu terdapat pengaruh yang signifikan atau positif antara materi pembelajaran PAI dan aktivitas pembelajaran PAI secara bersama-sama dengan penerimaan santri terhadap pluralitas. Adapun analisis statistiknya adalah sebagai berikut;

$$
\begin{aligned}
& r_{x 1 x 2}=\quad 178.117 \\
& \sqrt{ } \sqrt{((182.891))(200.875)} \\
& 178.117 \\
& \sqrt{\sqrt{191.672}}, 10 \\
& \text { 191.672, } 10 \quad r_{x 1 \times 2}=0,929
\end{aligned}
$$

Korelasi ini menunjukkan hubungan positif antara materi pembelajaran PAI dan aktivitas pembelajaran PAl secara bersama-sama dengan penerimaan santri terhadap kemajemukan, sebesar 0,929, jika diletakkan pada interval koefesien, ternyata sangat kuat. Adapun tingkat signifikan korelasinya adalah $r$ hitung $0,929>$ 0,175 dibandingkan dengan $r$ tabel. Korelasi in berlaku hanya untuk sampel penelitian, atas dasar itu akan dicari koefesien korelasi dengan populasi. Adapun perhitungan korelasi yang dapat diberlakukan secara generalisasi terhadap populasi yaitu santri sebagai peserta didik adalah sebagai berikut;

$$
\begin{aligned}
& \mathrm{t}=\quad \frac{0,929 \sqrt{\sqrt{110-43}}}{\sqrt{\sqrt{1-0,929^{2}}}}= \\
& 7,889 \\
& \mathrm{t}=\quad-\cdots, 588 \\
& \sqrt{ } \sqrt{0,137}
\end{aligned}
$$


Berdasarkan perhitungan koefesien korelasi di atas, t-hitung menunjukkan nilai sebesar 7,588, jika hasil tersebut dikonsultasikan dengan t-tabel yang menunjukkan sebesar 1,980 pada tingkat standar error $0,5 \%$, maka dapat disimpulkan bahwa koefesien korelasi penelitian menunjukkan bahwa hasil ini dapat diberlakukan secara generalisasi terhadap populasi, tidak terbatas pada sampel responden. Di mana r-hitung 7,588 > dibandingkan dengan t-tabel sebesar 1,980. Artinya secara generalisasi, santri sebagai populasi penelitian, mengakui bahwa materi pembelajaran PAI dan aktivitas pembelajaran PAI yang menentukan sikap penerimaan terhadap pluralitas.

Berdasarkan hasil uji hipotesis asosiatif tersebut di atas, maka dapat dibuatkan rangkuman adalah sebagai berikut;

Tabel. 4. 7 Rangkuman Pengujian Hipotesis alternatif

\begin{tabular}{|l|l|l|l|l|l|}
\hline No. & Variabel yang dikorelasikan & $\begin{array}{l}\text { r- } \\
\text { hitung }\end{array}$ & r-tabel & $r^{2}$ & Ket. \\
\hline 1. & Meteri PAl dengan penerimaan pluralitas & 0,927 & 0,175 & $\begin{array}{l}0,85 \\
9\end{array}$ & Signifikan \\
\hline 2. & $\begin{array}{l}\text { Aktivitas pembelajaran PAI dengan } \\
\text { pluralitas }\end{array}$ & 0,905 & 0,175 & $\begin{array}{l}0,81 \\
9\end{array}$ & Signifikan \\
\hline 3. & $\begin{array}{l}\text { Materi PAl dengan aktivitas pembelajaran } \\
\text { PAl }\end{array}$ & 0,929 & 0,175 & $\begin{array}{l}0,86 \\
3\end{array}$ & Signifikan \\
\hline
\end{tabular}

Sumber data: Hasil Analisis Korelasi Data Angket, 2015

4.2.4 Pengujian hipotesis dengan teknik analisis, yaitu Product Moment korelasi ganda $\operatorname{Ry} x_{1} x_{2}$ atau pengaruh dua variabel independen, yaitu antara materi pembelajaran PAI secara bersama dengan aktivitas pembelajaran PAI terdapat pengaruh positif atau hubungan signifikan terhadap penerimaan santri tentang pluralitas, dapat dihitung dengan rumus, adalah sebagai berikut;

$$
R_{y x_{1} x_{2}}=\sqrt{\begin{array}{c}
r^{2} y x_{1}+r^{2} y x_{2}-2 r y x_{1} r y x_{2} r x_{1} x_{2} \\
--------------- \\
1-r^{2} x_{1} x_{2}
\end{array}}
$$

dimana:

$\operatorname{Ry} x_{1} x_{2}=$ siginifikansi ganda antara $x_{1}$ dan $x_{2}$ secara berasama-sama dengan variabel $\mathrm{Y}$.

ry $x_{1}=$ korelasi sederhana antara $x_{1}$ dengan variabel

ry $x_{2}=$ korelasi sederhana antara $x_{2}$ dengan variabel $\mathrm{Y}$

$r x_{2}=$ korelasi sederhana antara $x_{1}$ dengan variabel $x_{2}$ dengan variabel $Y$ 


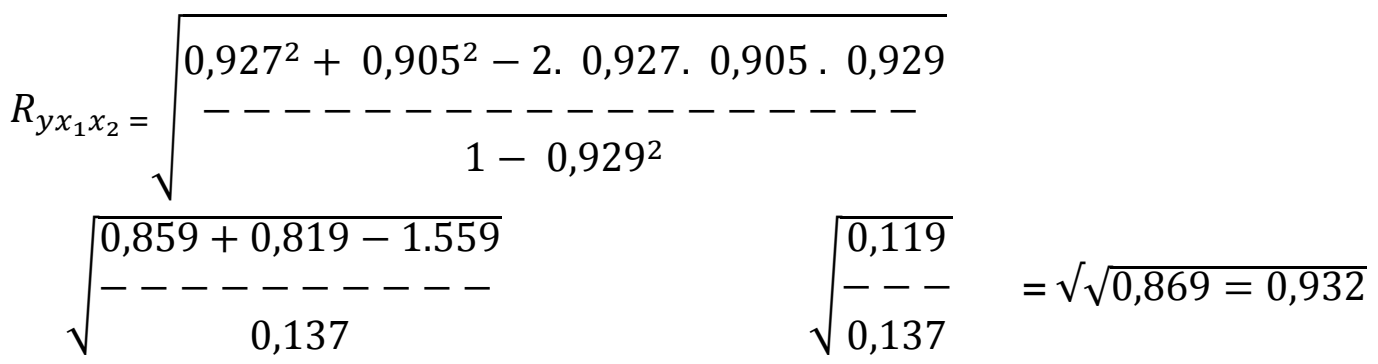

Jadi terdapat pengaruh positif dan signifikan antara materi pembelajaran PAI dan aktivitas pembelajaran PAI secara bersama-sama dengan penerimaan santri terhadap kemajemukan sebesar 0, 932. Meskipun hubungan ini secara kualitatif dapat dinyatakan sangat kuat, akan tetapi korelasi sebesar 0,932 baru berlaku untuk sampel responden yang diteliti. Apakah koefisien korelasi itu dapat digeneralisasikan untuk populasi, maka selanjutnya diuji signifikansinya, sebagai berikut;

$$
\begin{aligned}
& (0,932)(0,932) \\
& 2 \quad 0,434=28,970 \\
& F=\quad-107 \\
& (1-(0,932)(0,932)) \\
& (110-2-1)
\end{aligned}
$$

Hasil analisis data sebagaimana tersebut di atas, terhadap data yang bersumber dari responden, $F$ hitung sebesar 28,970. Selanjutnya harga dikomunikasikan dengan F-tabel berupa nilai distribusi $F$, menggunakan dk (derajat kebebasan) pembilang $=\mathrm{k}$ dan $\mathrm{dk}$ (derajat penyebut) $=(\mathrm{n}-\mathrm{k}-1) ; 110-2-1=107$, serta taraf kesalahan ditetapkan 0,5\%, maka diketahui F-tabel-nya $(1,36)$. Atas dasar memperhatikan data t-hitung $(28,97)$ dibandingkan dengan F-tabel ( 1,36), dapat disimpulkan bahwa terdapat pengaruh positif dan hubungan signifikan antara materi pembelajaran PAI (X1) dan aktivitas pembelajaran PAI (X2) secara bersama-sama dengan penerimaan santri tentang pluralitas (variabel $Y$ ). Meskipun terdapat pengaruh positif dari variabel $\mathrm{X} 1$ dan $\mathrm{X} 2$ terhadap variabel $\mathrm{Y}$, namun tingkat signifikansinya tidak terlalu kuat. Hal ini membuktikan bahwa penerimaan santri terhadap pluralitas masih dipengaruhi oleh faktor lain, bisa berupa lingkungan pembelajaran yang menjadi tradisi di pesantren.

\section{Pembahasan}

Setelah dilakukan uji hipotesis secara deskriptif dan uji analisis secara asosiatif terhadap dua variabel independen dan satu variabel dependen, selanjutnya akan dianalisis dan diinterpretasi maknanya. Penyajian data melalui pemaparan secara deskriptif dan analisis statistik, hasil dari proses penelitian, ternyata menunjukkan adanya butkti kuat yang dapat dijadikan dasar untuk menganalisis kecenderungan penerimaan santri tentang kemajemukan di tengah-tengah masyarakat. Penerimaan positif ini, dipengaruhi oleh dua faktor yang determinan, yaitu faktor materi Pembelajaran PAI dan aktivitas pembelajaran PAI yang diterapkan di pensantren Puteri DDI Ujung Lare Kota Parepare. Dengan demikian itu, Pesantern Puteri DDI 
Ujung Lare telah mengaplikasikan prinsip kesetaraan, bahwa aspek terpenting dalam pendidikan multikultural adalah kesetaraan dan keadilan sosial.

Penafsiran dan anlisis data deskriptif dan terhadap data yang dikorelasikan, sebagaimana hal berikut ini;

Materi pembelajaran PAI

Data dari hasil t hitung 7, 347, sesuai dk (derajat kebebasan) sebesar 110 -1 $=139$, dan menggunakan taraf kesalahan 0,5\%, maka diperoleh hasil bahwa ternyata t- hitung sebesar 7,347 ternyata lebih besar dari pada t-tabel 1,980. Hal ini menunjukkan bahwa materi pembelajaran PAI merupakan salah satu instrumen sumber pembelajaran yang secara positif dapat mempengaruhi sikap dan penerimaan santri terhadap kemajemukan. Kecenderungan positif ini juga disebabkan oleh sistem pesantren sejak awal mengembangkan pola hidup yang berdasar pada tradisi keagamaan yang sangat memperhatikan aspek-aspek toleransi dan kebersamaan. "Para santri sudah terbiasa hidup untuk saling memahami keragaman/kemajemukan baik dalam pendidikan, status sosial, maupun dalam persoalan SARA (suku, ras, agama, dan bangsa), dan juga etnis."

Materi pembelajaran PAI mempunyai implikasi terhadap santri, hal ini dapat dipahami, bahwa "Pendidikan Agama Islam (PAI) memberikan kontribusi terhadap santri mengenai pluralisme. Karena itu merupakan pandangan yang mempunyai nilai positif. Implikasi yang dimaksud mengenai hal yang lebih luas, adalah sebagai berikut; Implikasi terhadap pemahaman santri mengenai agama, oleh karena materi PAI banyak berisi secara tersurat maupun implisit tentang pandangan kemajemukan (pluralisme) dalam agama Islam, maka hal ini sudah barang tentu dapat merekonstruksi pengetahuan, pemahaman, dan pandangan santri ke arah yang lebih toleran, moderat, atau berpandangan inklusif.

4.3.1.2 Implikasi terhadap sikap sosial santri mengenai kemajemukan, bahwa pengetahuan, pemahaman, dan pandangan merupakan unsur-unsur yang mempunyai nilai konstruktif terhadap pembentukan sikap sosial santri. Dari pengetahuan yang toleran dan moderat, maka santri akan menjadikannya sebagai unsur kognitif dalam pembentukan sikap (afektif) sosialnya. Untuk penbentukannya, terdapat beberapa pilar utama yang diperlukan untuk menguatkan sikap mental, sikap etis, dan sifat-sifat kejiwaan, yaitu adalah sebagai berikut; (1) cinta pada Tuhan yang dimanifestasikan dalam bentuk cinta terhadap alam semesta, manusia dan lingkungan, (2) bertanggung jawab, kejujuran hormat dan santun, (3) motivasi yang kuat untuk maju disertai optimisme yang tinggi, (4) berlapang hati, dan membangun empati.

Pertama, uji hipotesis dengan satu variabel (diskreptif), menunjukkan bahwa t-hitung $=4,105$, sesuai dk (derajat kebebasannya) sebesar $110-1=109$, dan menggunakan taraf kesalahan $5 \%$, maka diperoleh hasil bahwa ternyata t- hitung sebesar 4, 105 terletak di luar harga t-tabel, yaitu 1, 656. Hal ini dapat disimpulkan 
bahwa hipotesis yang menyatakan bahwa materi pembelajaran PAI berisi muatan kemajemukan dikategorikan berada pada level di atas sedang, diterima. Kedua, uji hipotesis asosiatif untuk sampel saja, membuktikan koefesien korelasinya terletak pada interval koefesien 0,80 - 1,00, maka korelasi ini termasuk korelasi yang kuat, sebesar 0,927. Hasil korelasi ini jika dibandingkan r-tabel ternyata lebih tinggi. Perbandingannya adalah 0,927 ( $r$ hitung) $>0,175$ ( $r$ tabel). Ketiga, uji hipotesis asosiatif untuk populasi, membuktikan bahwa sesuai uji t test, maka diperoleh thitung sebesar 7,347 dan jika dikonsultasikan dengan t-tabel untuk kesalahan (nilai error) $0,5 \%$, maka diketemukan t-tabel 1,980. Dengan demikian, dapat dinyatakan bahwa hipotesis alternatif yang diterima, sementara hipotesis nol ditolak. Jadi kesimpulannya koefesien korelasi antara materi pembelajaran PAI dengan sikap, pandangan terhadap penerimaan kemajemukan sebesar 7,347 adalah signifikan, dan dapat digeneralisasi terhadap populasi.

Hasil analisis data tersebut di atas, menunjukkan bahwa materi pembelajaran PAI di Pondok Pesantren Puteri DDI Ujung Lare Kota Parepare berimplikasi kuat terhadap sikap penerimaan santri terhadap pluralitas. Bahwa keberadaan suatu masyarakat didasari pada pilar-pilar kemajemukan seperti kebersamaan, persaudaraan, selama ini telah menjadi pola hidup yang terbangun di pesantern. "Para santri sudah terbiasa hidup dengan cara hidup pesantren; bersahaja, mandiri, kebersamaan, persaudaraan, toleransi. Dengan cara hidup seperti ini, akan menentukan sikap dan pandangan mereka terhadap pluralitas sosial di masyarakat".

\subsubsection{Aktivitas Pembelajaran PAI}

Kegiatan pembelajaran PAI, seperti halnya materi PAI, mempunyai signifikan terhadap proses penerimaan santri terhadap pluralitas. Hal ini dibuktikan dari hasil uji hipotesis terhadap satu variabel (deskriptif) dan juga hasil uji hipotesi terhadap korelasi antara dua variabel (asosiatif).

Pertama, uji hipotesis atas satu variabel (deskriptif) menunjukkan bahwa hasil perhitungan pengolahan data, yaitu $\mathrm{t}-$ hitung sebesar 5,862, ternyata terdapat perbedaan dengan apa yang diduga (hipotesis), hal ini sebagai bukti bahwa hipotesis alternatif diterima. Berdasarkan t hitung 5,862, disesuaikan dk (derajat kebebasannya) sebesar $110-1=109$, dan menggunakan taraf kesalahan 0,5\%, sehingga t- hitung sebesar 5, 862 terletak di luar harga t-tabel 1,656. Jadi dapat disimpulkan bahwa hipotesis yang menyatakan aktivitas pembelajaran PAI mengandung muatan kemajemukan berada pada kategori sedang, ditolak. Karena datanya, sesuai hasil perhitungan uji data deskriptif, membuktikan di atas kategori sedang ( $t$ hitung $=5,862>$ t-tabel $=1,656$ ). Kedua, hasil uji hipotesis dua variabel untuk sampel penelitian, menunjukkan adanya korelasi antara aktivitas pembelajaran PAI dengan penerimaan santri terhadap kemajemukan sebesar 0,905, jika diletakkan pada interval koefesien, ternyata sangat kuat. Adapun tingkat signifikan korelasinya adalah $r$ hitung 0,905 > 0,175 dibandingkan dengan $r$ tabel. Korelasi in berlaku hanya untuk sampel penelitian, atas dasar itu akan dicari koefesien korelasi dengan 
populasinya. Ketiga, hasil uji hipotesis dua variabel untuk populasi. Berdasarkan perhitungan koefesien korelasi di atas, t-hitung menunjukkan nilai sebesar 7,588, jika hasil tersebut dikonsultasikan dengan t-tabel yang menunjukkan sebesar 1,980 pada tingkat standar error 0,5\%, maka dapat disimpulkan bahwa koefesien korelasi menunjukkan bahwa hasil ini dapat diberlakukan secara generalisasi terhadap populasi, tidak terbatas pada sampel responden. Di mana r-hitung 7,588 > dibandingkan dengan t-tabel sebesar 1,980. Artinya secara generalisasi, santri sebagai populasi penelitian, mengakui bahwa materi pembelajaran dan aktivitas pembelajaran PAI yang menentukan sikap penerimaan terhadap pluralitas.

Data tersebut di atas, menggambarkan bahwa aktivitas pembelajaran yang dimediasi oleh guru senantiasa memberikan ruang pemahaman yang luas kepada santri tentang kemajemukan. Pembelajaran PAI tidak menafikkan terhadap adanya entitas dan identitas etnik, agama, suku, sebagai pilar keutuhan masyarakat. Karenanya, aktivitas pembelajaran PAI berupaya membentuk sikap sosial yang baik kepada santri. Di antara tujuan pendidikan multikultural adalah transformasi diri yang bertujuan mengenal identitas diri merupakan titik permulaan menghubungkan guru, siswa, dan lingkungan yang menjadi pilar dasar dalam proses pembelajaran.

Aktivitas pembelajaran PAI sedapat mungkin memperhatikan segi metodologinya adalah sebagai berikut;

4.3.2.1 Proses pembelajaran diselenggarakan secara interaktif, inspiratif, motivatif, menciptakan ruang kreativitas, rasa ingin tahu dan kemandirian serta menempatkan santri sebagai subyek pendidikan, mitra dalam proses pembelajaran baik sebagai peserta didik, umat ataupun anggota masyarakat.

4.3.2.2 Proses pembelajaran diselenggarakan memperhatikan aspek-aspek edukatifnya, mengembangkan daya kritis, reflektif, analitis, melalui dialog partisipatoris untuk mencapai pemahaman tentang substansi kebenaran dari bahan ajar PAI.

4.3.2.3 Proses pembelajaran diselenggarakan dengan cara menumbuhkan kesadaran santri untuk mengartikulasikan nilai-nilai materi PAI, termasuk nilai-nilai pluralitas/kemajemukan, mental dan sikap sosial, agar menjadi bagian yang menyatu dengan diri pribadi santri.

4.3.3 Uji hipotesis variabel X1 dan variabel X2 (materi dan aktivitas pembelajaran PAI), apakah terdapat pengaruh secara signifikan dan kuat terhadap penerimaan santri tentang pluralitas. Sesuai dengan hasil analisis data, maka terdapat korelasi positif dan signifikan antara materi pembelajaran PAI dan aktivitas pembelajaran PAI secara bersama-sama dengan penerimaan santri terhadap kemajemukan sebesar 0 , 932. Meskipun hubungan ini secara kualitatif dapat dinyatakan sangat kuat, akan tetapi korelasi sebesar 0,932 baru berlaku untuk m,osampel responden yang diteliti. Apakah koefisien korelasi itu dapat digeneralisasikan untuk populasi, maka selanjutnya dicari tingkat signifikansinya. 
Hasil analisis terhadap data yang bersumber dari responden, $\mathrm{F}$ hitung sebesar 28,97. Selanjutnya harga dikomunikasikan dengan F-tabel berupa nilai distribusi $F$, menggunakan $\mathrm{dk}$ (derajat kebebasan) pembilang $=\mathrm{k}$ dan $\mathrm{dk}$ (derajat penyebut) $=(\mathrm{n}-$ k-1); $110-2-1=107$, serta taraf kesalahan ditetapkan 0,5\%, maka diketahui F-tabelnya 1,36 . Atas dasar memperhatikan data t-hitung $(28,97)$ dibandingkan dengan Ftabel ( 1,36), maka dapat disimpulkan bahwa terdapat korelasi positif dan hubungan signifikan antara materi pembelajaran PAI (X1) dan aktivitas pembelajaran PAI (X2) dengan penerimaan santri tentang pluralitas (variabel Y). Sekaligus data tersebut di atas, menunjukkan adanya pengaruh secara positif antara variabel yang ada, namun pengaruh itu berada pada tingkat signifikansinya tidak terlalu kuat. Gejala ini dapat disebabkan oleh faktor tradisi keagamaan dan pola relasi yang terbangun di pesantren selama ini. Selain materi PAI dan aktivitas pembelajaran PAI sebagai hal yang dominan, terdapat juga faktor yang lain yang mempengaruhi perkembangan pandangan kemajemukan atau pluralitas di kalangan santri.

4.3.3.1 Pada prinsipnya pandangan kemajemukan dimiliki oleh santri sejalan dengan tradisi keagamaan yang selama ini diaplikasikan dalam kehidupan pesantren. 4.3.3.2 Terbentuknya pandangan tentang kemajemukan di kalangan santri sedikit banyaknya dilatarbelakangi oleh hal, yaitu (1) doktrin ajaran agama, terutama terhadap sikap sosial sebagai anggota masyarakat (2) doktrin ajaran agama seperti ini terikat dengan azas tanggung jawab moral dan kewajiban moral. (3) pandangan keagamaan yang dikembangkan di Pondok Pesantren Puteri DDI Ujung Lare bercorak moderat, toleran, dan inklusif. Hal ini merupakan modal utama bagi santri untuk memahami dan menerima segala bentuk perbedaan dalam lingkup sosial yang lebih luas, termasuk perbedaan keyakinan. Pluralitas keyakinan, dan yang lainnya seperti etnik merupakan kenyataan yang diakui keberadaannya oleh Al-Qur'an dan Al-Hadits, ke duanya sumber materi PAI, maka seyogiyanya para santri menerima hal itu sebagai bagian dari ajaran agama Islam.

4.3.3.2 Ekosistem lingkungan pesantren merupakan wadah yang tepat yang dapat memfasilitasi tumbuh dan berkembangnya pandangan inklusif keagamaan di kalangan santri. Sehingga persoalan-persoalan tentang perbedaan yang terjadidi lingkungan sosial dengan mudah dapat dipahami, direspon, bahwa setiap perbedaan entitas harus terus dipertahankan keberadaannya berdampingan dengan entitas lainnya.

Pandangan pluralitas santri terbentuk dengan pemahaman disertai pengetahuan yang benar. Sehingga berimplikasi terhadap sikap penerimaan mereka terhadap pluralitas. Jadi pengetahuan pluralitas yang dimiliki oleh santri ternyata berdampak terhadap sikap dan mental meraka, yang pada gilirannya mereka memiliki sikap sosial yang baik. Adapun beberapa hal yang turut serta mempengaruhi wawasan dan penerimaan santri terhadap pluralitas di Pondok Pesantren Puteri DDI Lil Banat Ujung Lare. 


\section{KESIMPULAN}

1. Sumber pembelajaran yang dikembangkan di pesantren selama ini berorientasi pada pluralitas. Baik materi pembelajaran PAI maupun tradisi keagamaan yang diselenggarakan melalui kegiatan ekstrakurikuler dan kokurikuler senantiasa memperhatikan ajaran persamaan, persamaan, persaudaran, dan kasih saying dalam agama Islam.

2. Lingkungan pembelajaran juga turut serta memberikan kontribusi yang positif terhadap pandangan dan penerimaan santri terhadap pluralitas. Di dalam lingkungan pembelajaran tercipta dan terbangun suasana untuk saling menghargai perbedaan dan latarbelakang ekonomi dan pendidikan serta pekerjaan orang tua. Meskipun kondisi ini bersifat internal pesantren, namun demikian dapat berfungsi sebagai modal dasar untuk memahami persoalan perbedaan atau keragamaan sosial yang lebih luas di lingkungan masyarakat.

3. Tipologi sumber pembelajaran agama yang berakar di Pesantren Puteri DDI Lil Banat adalah pemahaman agama yang bercorak moderat, toleran dan inklusivisme. Suatu sikap keagamaan yang menempatkan perbedaan dan latarbelakang keragamaan sosial dalam kerangka potensi keutuhan sosial dari pada melihatnya sebagai potensi kecemburuan, kerusuhan, dan konflik.

4. Pola relasi sosial internal santri yang menjadi tradisi interaksi didasarkan pada prinsip kesetaraan, kesamaan, kebersamaan, dan keterbukaan menerima perbedaan yang ada, meskipun sifatnya internal pesanteren. Akan tetapi merupakan bagian dari proses pematangan pandangan santri tentang pluralitas.

\section{Daftar Pustaka}

[1] Hakim, Lukmanul. "Pandangan Islam tentang Pluralitas dan Kerukunan Umat Beragama dalam Konteks Negara", Harmoni: Jurnal Multikultural dan Multireligius, Volume X, Nomor 1, Januari-Maret 2011.

[2] Hatta, Ahmad. Tafsir Qur'an Perkata Dilengkapi dengan Asbabun Nuzul dan Terjemah. Cet. III; ( Jakarta: Maghfirah Pustaka, 2009.

[3] Hj. St. Awaliyah, Wawancara. "Guru Madrasah Tsanawiyah DDI Lil Banat", Wawancara, di PP. Puteri DDI Lil Banat,tanggal 25 Mei 2015.

[4] Jamaliah, Wawancara. "Guru Pondok Pesantren Puteri DDI Ujung Lare Kota Parepare", di PP. Puteri DDI Ujung Lare, tanggal $27-11-2015$.

[5] Kasmawati, Wawancara. "Guru Pondok Pesantren Puteri DDI Ujung Lare Kota Parepare", di PP. Puteri DDI Ujung Lare, tanggal 25-11- 2015.

[6] Megawangi, Ratna. "Pendidikan Berbasis Karkater", Majallah ESQ Nebula Mencerdaskan Emosi dan Spritual, Nomor 16 Tahun 2012.

[7] Salim, Agus. Stratifikasi Etnik Kajian Mikro Sosiologi Interaksi Etnis Jawa dan China, Cet.I; (Tiara Wacana, Semarang: 2006.

[8] Truna, Dody S. Pendidikan Agama Islam berwawasan Multikulturalisme Telaah Kritis atas Muatan Pendidikan Multikulturalisme dalam Buku Ajar Pendidikan Agama Islam (PAI) di Perguruan Tinggi Umum di Indonesia, Cet. I; ( Jakarta: Kementerian Agama RI, 2010. 